\title{
Problems and Prospects of Introduction of the Indemnity Institute in the Civil Law of Ukraine
}

\author{
Volodymyr Volodymyrovych Stetsenko \\ Institute of International Relation, \\ Taras Shevchenko National University of Kyiv \\ Vladimir.v.stetsenko@gmail.com
}

\begin{abstract}
This article considers the possibility of introducing the institute of "indemnity" in the legislation of Ukraine. It is proposed to review approaches to the definition of the obligation to compensate losses arising in the event of materialisation of the conditions set out in the agreement, to classify such obligation, identify the potential place of such obligation in the law of Ukraine.
\end{abstract}

Keywords: indemnity, losses.

\section{Introduction}

In the conditions of the development of the modern Ukrainian economy, there is a significant increase in the participation of foreign investors in the capital of Ukrainian companies. Such changes in economy lead to a significant increase in agreements with foreign counterparts for the privatisation, sale and purchase of shares in commercial enterprises. Nevertheless, most of these agreements are governed by the law of England and Wales. Among the reasons for this choice is the possibility of using more effective instruments to protect the interests of the parties, which are not provided by national legislation.

For example, the parties to a contract for the purchase and sale of the commercial company shares, in the process of reaching an agreement on the essential terms, discovered that a company whose corporate rights are the subject of the contract received a tax notice, i.e. imposing a fine in a substantial amount. The seller party wishes to conquer such a dispute with the tax authority in order to cancel the fine rather than discount 
the corporate rights price in the amount of the fine imposed. Then the parties who have agreed to subordinate their contract to the law of England and Wales, have the opportunity to prescribe an indemnity for losses in the amount of $\mathrm{X}$ or in full amount if, after the execution of the contract as a result of the appeal of the tax notice-decision will stay valid. In this way, the buyer will be able to protect himself from losses that may occur in the future and which are not dependent on his will and/or actions, and the seller has the opportunity to obtain the full price for the item of sale without the need for discounting due to potential risk.

In Ukraine, such a tool to protect the interests of the buyer would not have been taken by the court due to the fact that the domestic legal doctrine treats claims for such obligations as a claim for damages, and the concept of losses stipulated in the Ukrainian civil law specifies luminous composition of elements that the concept of "indemnity" does not fit.

The author considers it expedient to show the potential place of "indemnity" in the system of English law obligations, to identify the nature of such obligations and to open up the opportunity of introducing an indemnity in the law of Ukraine by fixing the relevant changes in the legislation.

\section{Literature data analysis and problem statement}

The solution to this problem can be facilitated by the development in the legislation of Ukraine of the design of compensation for losses that arise in the event of the circumstances specified in the contract. To determine the possibility of developing such a structure in the current legislation of Ukraine, the Author analysed the civil legislation, institutes of consequences and liability for breach of obligations, system of ways of compensation for harm, legal consequences of breach of obligation; identified the most related ways to ensure obligation fulfilment based on the design of loss compensation.

Scientific and theoretical studies of the legal regulation of the instruments of protection of interests of the parties to the obligation from the civil legal point of view were carried out by such domestic and foreign scientists as H. Bill, O. V. Dzera, A. S. Dovgert, A. G. Karapetov. N. S. Kuznetsova, L. O. Novosyolova, A. P. Rudnev, A. R. Sviatoshniuk, O. V. Tomisinov, and many others.

\section{Aim}

The aim of the article is to investigate the possibility of introducing the institute of "indemnity" in the legislation of Ukraine, to identify its potential place in the system of obligations and to make appropriate proposals for improvement of the current legislation of Ukraine. 
Volodymyr Volodymyrovych Stetsenko. Problems and Prospects of Introduction of the Indemnity Institute in the Civil Law of Ukraine

\section{Results}

To identify the indemnity in the English contract law obligations system, the Author referred to the definition of indemnity itself in the practice of the English law and in accordance with the legal framework in other jurisdictions.

English law classically approaches the "indemnity" definition by treating the construction by the court. One of the central precedents of the English law raises the question of the definition of "indemnity" being interpreted in this concept.

First, there is no established approach to the definition of "indemnity" in the English law. This status quo is governed by the rule of wording "indemnity". In the case referred to, two definitions are provided, where, according to the first, "indemnity" are losses and, according to the second, an obligation to pay all losses (See Total Transport Corporation $v$ Arcadia Petroleum Limited [1997] EWCA Civ 2754 (18 November, 1997). In the context of the practical application as well as the implementation of this institute in other jurisdictions, the second approach to the definition is the basic one. Such approach seems a more logical because "damages" are familiar and similar in both English, Roman, and Ukrainian legal systems. In the Ukrainian doctrine, the composition of the offense is classic and requires all the elements necessary for the occurrence of liability: unlawful conduct, harm, the causal link between the unlawful conduct of the offender and harm, guilt (See the Supreme Court of Ukraine Resolution 908). / 2138/16 dated August 9, 2017.).

Second, "indemnity" is a primary obligation by its nature, which involves only one element - the occurrence of circumstances prescribed in the contract. This means that the obligation does not arise as a result of breach of other obligations under the contract, it is reasonably "foreseeable" and the requirement to fulfil it does not need to be proven.

Third, the parties should clearly state the obligation that its performance does not intersect with damages, such obligation is not a penalty, and such obligation must be conditioned on the subject matter of the obligation under contract (the condition of the company being acquired, the requirements for the subject of the main transaction, etc.).

Next, the indemnity obligation is not contingent on the fulfilment of any other contractual obligations and will only arise in the event of circumstances that the parties have agreed to in the future. The concept of "indemnity" also contains a number of other conditions that affect law enforcement, the examples of implementation of which will be looked at in other legal systems.

Thus, it can be concluded that "indemnity" is a separate type of obligation that arises as a result of certain circumstances in the future, whereby the "guilty" party has to pay to the "injured" party all the losses suffered by the "injured" party due to the materialisation of the agreed circumstances.

By its economic nature, indemnity balances the value of the asset being acquired. A buyer who has become aware of the existence of a defect which, in the future, when 
Volodymyr Volodymyrovych Stetsenko. Problems and Prospects of Introduction of the Indemnity Institute in the Civil Law of Ukraine

such an asset passes into his property, will cause certain losses, may protect his economic interest both in the part of the price paid, which corresponds to the losses incurred and in the amount of the losses incurred. Otherwise, the parties would have to discount the price, which would lead to a certain conflict, as the stipulated circumstances may not occur, which in turn will not meet the interests of the seller. Very often, the buyer refuses to enter into contractual relations if the seller does not agree to take "indemnity".

Undeniable is the fact that domestic doctrine does not have a tool that could sufficiently and transparently protect the interest of the buyer regarding the losses that may occur in the future. In turn, the question arises as to how such a structure might exist in the domestic legal system? [3,3] Considering the fact that "indemnity" has a connection with the basic obligation but does not depend on its fulfilment, and therefore may not depend on the actions of the parties in the future, it can be argued that "indemnity" does not refer to legal consequences of the obligation breach.

However, such consequences provided for by Article 611 of the Civil Code of Ukraine are related to the purpose of mechanisms for protecting the rights and interests of the parties to the obligation. Unilaterally waiving obligations, terminating the contract and changing the terms of the obligation generally do not involve monetary compensation and are therefore not related to the subject of indemnity. The penalty as part of how to ensure that the obligation is fulfilled will be looked at.

Related to the subject are legal consequences in the form of damages and nonpecuniary damage. The concepts of real loss and loss of profit imply that the party will be compensated for the loss suffered or loss of profit in connection with a violation of civil law. The main differences between these civil rights are the right from which they arise, the need to prove the amount of compensation and the limited establishment of contractual circumstances in which the party could obtain compensation for its losses.

The closest to indemnity, according to the Author, are the categories of real losses and lost profits. The similarity of lost profits, real losses and indemnity is that they imply the return of the injured party to the position in which such a party would be in the absence of a breach of obligation. However, in the case of lost profits, it has to be proved that, under normal circumstances, there would be no corresponding losses, which makes it impossible to secure such a position (in a negative form) in the contract. Indemnity, in turn, is not a design that supersedes or prevents the institute from applying the legal consequences of a breach of obligation. It can be concluded that the construction of guarantees for damages does not replace the legal consequences of non-compliance with the Ukrainian legislation.

As that, obligation enforcement is aimed at protection of the interests and rights of the parties, the classic types of obligation enforcement have been looked at for the current legal system, analysing the advantages and disadvantages to indemnity.

According to Article 546 of the Civil Code of Ukraine, performance of the obligation can be secured by a forfeit, a guarantee, a bank guarantee, a pledge, retention title, a deposit, a right of trust. 
Volodymyr Volodymyrovych Stetsenko. Problems and Prospects of Introduction of the Indemnity Institute in the Civil Law of Ukraine

According to the Civil Code of Ukraine, a forfeit (fine, penalty) is a sum of money or other property that the debtor must transfer to the creditor in case of breach of the debtor's obligations. First, a penalty is a secondary obligation that results from a breach of the primary obligation that is enforced. Second, the penalty requires a sufficiently precise determination of the amount of the payment, which affects the full protection of the interests of the injured party. Thus, the penalty does not cover the amount of casualty losses that may occur after the initial obligation is fulfilled. [5, 69]

Guarantee and warrantee are secondary obligations that ensure the fulfilment of the principal obligation by the substitute guarantor or warrantor. Similarly to penalty, these obligations do not cover the full extent of the loss suffered by the injured party, and are applicable to the composition that includes intentional activity of the breaching party.

Pledge, retention title and trust property are the instruments that can enforce the claim in the future but are secondary obligations in relation to the underlying obligation, provide that, in the event of a breach of the underlying obligation, the subject of pledge, retention or trust can be claimed.

It can be argued that all types of liability provided for in this article are secondary and the extent of the party's risk coverage is substantially limited to the category of damages. The primary function of enforcing the obligation is that it is an active action or restraint of the actions of the party that depend on the will of that party. The essence of "indemnity" is that the obligation to compensate for the loss arising from the occurrence of a certain legal fact, which can be both an act and an event that will not depend on the behaviour of the party or its will.

In view of the above, it is believed that the potential implementation of such an institute should occur through the introduction of a separate design in civil law, which would govern the obligation to compensate for losses arising from the occurrence of circumstances specified in the contract. Such a conclusion is due to the characteristic of the domestic jurisdiction of the certainty of the instruments of protection of interests of the parties in the contractual relations, the need for correct interpretation in the law enforcement and the need for a clear interpretation of such instrument by the court.

This conclusion has been reached in the process of analysing legislation where "indemnity" was recently introduced into the liability system. For example, in 2015, the Civil Code of the Russian Federation was supplemented by Article 406-1 "Compensation for losses arising in the event of circumstances specified in the contract". The wording of the provision in Article 1, Paragraph 1, very cleverly reveals the essence of the mechanism:

"The parties to the obligation, acting in the course of their business activities, may by their agreement provide for the obligation of one party to compensate for the material losses of the other party, arising in the event of circumstances specified in such agreement and not related to the breach of the obligation by his party. (Losses caused by the inability to fulfil the obligation, by making claims to third parties or bodies of the state $\mathrm{x}$ authority to the party or third party specified in the agreement, etc.). The agreement of the parties shall specify the amount of compensation for such losses or the procedure for determining it." 
Volodymyr Volodymyrovych Stetsenko. Problems and Prospects of Introduction of the Indemnity Institute in the Civil Law of Ukraine

In turn, Paragraphs $2-5$ of the Article 406-1 set out the basic principles for using the tool:

- the court cannot reduce the amount of damages unless it is proved that the party intentionally contributed to the increase of losses;

- the losses stipulated in the article are compensated irrespective of the fact that the contract is not concluded or invalid;

- if the losses have occurred as a result of the misconduct of third parties, the claim for damages shall be transferred to the party who made the compensation;

- the rules of this article shall also apply where the condition for compensation for losses is enshrined in a corporate agreement or a contract of alienation of shares or shares in the authorized capital of a commercial company to which the individual is a party.

For the most part, these principles reflect a number of characteristic features of "indemnity" that have been described above. Analysing the implementation of the new design, it should be noted that as a result of the courts reviewing the disputes on the interpretation of the principles of application of the instrument, a decision of the Plenum of the Supreme Court of the Russian Federation of March 7, 2016 No. 7 "On the application by the courts of some provisions of the Civil Code on liability for breach of the obligation" $[2,3]$. This decision further stipulates that in the event of a party promoting the circumstances specified in the contract, such circumstances shall be deemed not to have occurred, and that the obligation to compensate for the loss must be clear and understandable. Unless the obligation is clearly stated, the provisions of Article 406.1 shall not apply $[1,454]$. In fact, case law has filled in some of the gaps that would arise during enforcement.

The design introduced in Russian law is a good example of the formulation of a new type of obligation for a conservative legal system. This example of implementation shows that constructions similar to the classic Anglo-Saxon tool for protecting the interests of the parties can be implemented in conservative continental regulation, although such an institute does not apply to classical insurance or contractual liability.

\section{Conclusions}

As a result of the study, it was found that the design of compensation for losses arising in the event of circumstances specified in the contract is not inherent in Ukrainian law because it contravenes a number of fundamental provisions by its mechanism of action. Contractual indemnity does not imply the need to prove the extent of the loss suffered by the legal entity. Indemnity is not related to a breach of a principal obligation and is a primary obligation. Indemnity may be spelled out in the contract as a liability arising out of certain circumstances that are not dependent on the will or actions of the parties.

The prospect of introducing a cost-recovery framework in the event of circumstances specified in the contract requires a deeper study of the Roman legal family laws. 
The potential implementation of "indemnity" is possible only in the form of a contractual obligation, and such implementation requires a detailed settlement of the contractual obligation, which will neither relate to damages nor to other legal consequences of nonfulfilment of the basic obligation under the contract. Also, "indemnity" cannot conflict in action and right it arises out of with enforcement the obligation.

As the right to protect the interests of the parties in the contractual obligations lacks a tool for certain risks and thus does not fully cover the interests of the parties, the prospects for the implementation of the most successful and exemplary instruments are not far-sighted and in the experience of neighbouring jurisdictions inevitable. That is why the development of "indemnity" must continue at a high scientific level.

\section{Kompensācijas institūta ieviešanas problēmas un perspektīvas Ukrainas civiltiesībās}

\section{Kopsavilkums}

Šajā rakstā tiek analizēta iespēja Ukrainas tiesību aktos ieviest "kompensāciju" institūtu. Tiek ierosināts pārskatīt pieejas attiecībā uz pienākuma kompensēt zaudējumus definēšanu, kas radās vienošanās nosacījumu materializācijas gadījumā, klasificēt šādu pienākumu, noteikt šāda pienākuma iespējamo vietu Ukrainas tiesību aktos.

Atslēgvārdi: kompensācija, zaudējumi.

\section{References}

1. Karapetov, A. G., Savelyev A. I. 2012. Freedom of contract and its limits. In A. G. Karapetov in 2 vols. M., Charter, p. 453.

2. Karapetov, A. G. 2016. Condition for Compensation for Losses: Commentary on Article 406.1 of the Civil Code. Bulletin of Economic Justice of the Russian Federation, 5, 2016. [Electronic resource]. Access mode: https://www.m-logos.ru/img/Karapetov-Indemniti.pdf

3. Svyatoshniuk, A. R. 2014. Loss indemnity as a legal implication of contractual delinquency. Bulletin of the Odessa National University. Jurisprudence, 19, 4 (25). [Electronic resource]. Access mode: http://dspace.onu.edu.ua:8080/handle/123456789/7016

4. Tomsinov, A. V. 2015. Statement of Circumstances and Compensation in Russian Law in Comparison with Representations, Warranties and Indemnity in the Law of England. In Bulletin of Economic Justice of the Russian Federation, 91-111.

5. Verkhovets, A. A. 2010. Civil liability for breach of contract: author's abstract diss. for the sciences. Kiev, pp. 66-74. 